Document downloaded from:

http://hdl.handle.net/10251/149552

This paper must be cited as:

Torregrosa, AJ.; Broatch, A.; Novella Rosa, R.; Gómez-Soriano, J.; Monico Muñoz, LF. (2017). Impact of gasoline and Diesel blends on combustion noise and pollutant emissions in Premixed Charge Compression Ignition engines. Energy. 137:58-68. https://doi.org/10.1016/j.energy.2017.07.010

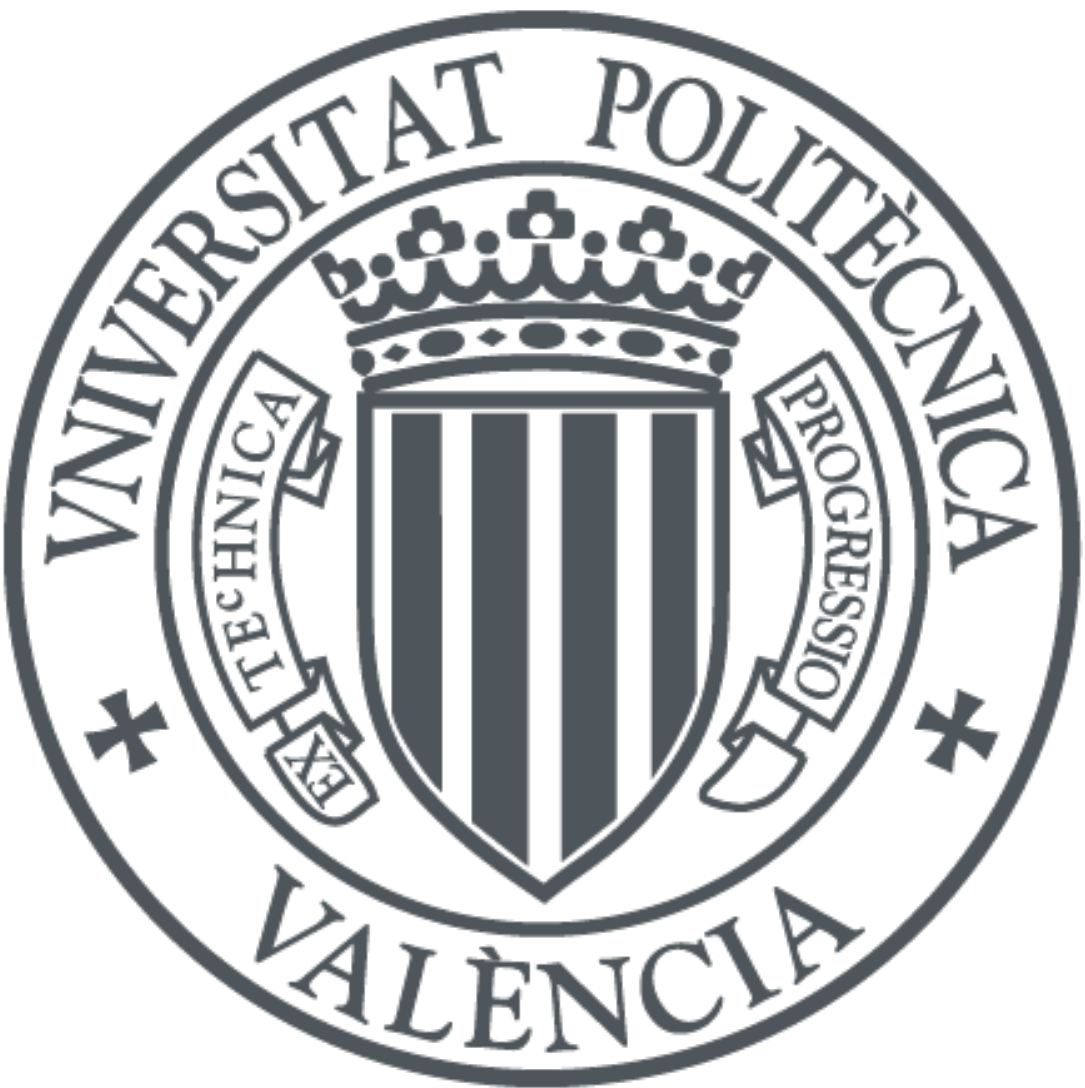

The final publication is available at

https://doi.org/10.1016/j.energy.2017.07.010

Copyright Elsevier

Additional Information 


\title{
Impact of gasoline and Diesel blends on combustion noise and pollutant emissions in Premixed Charge Compression Ignition engines
}

\author{
A.J. Torregrosa ${ }^{\mathrm{a}}$, A. Broatch ${ }^{\mathrm{a}, *}$, R. Novella ${ }^{\mathrm{a}}$, J. Gomez-Soriano $^{\mathrm{a}}$, L.F. Mónico ${ }^{\mathrm{b}}$ \\ ${ }^{a}$ CMT-Motores Térmicos, Universitat Politècnica de València, Aptdo. 22012, E-46071 Valencia, Spain. \\ ${ }^{b}$ Programa de Ingeniería Aeronáutica, Universidad de San Buenaventura, Carrera 8H No. 172 - 20, Bogotá, Colombia.
}

\begin{abstract}
Research efforts in the automotive sector focus on developing new combustion concepts for mitigating the emissions of nitrous oxides and soot of conventional Diesel combustion. One of the most promising concept is the Premixed Charge Compression Ignition. In this, the fuel burns in premixed conditions, avoiding the formation of soot whereas nitrous oxides are controlled using large amounts of exhaust gas recirculation. Because of the premixed combustion, high fuelburning velocities are produced, whence combustion noise is deteriorated. In order to mitigate this drawback, different blends of gasoline and Diesel fuels are being considered due to their suitability for this combustion characteristics. The effect of these fuel blends on emissions, performance and engine noise is analysed in this paper with the aim to provide additional knowledge of the fundamental issues of this particular combustion mode. The study also includes sweeps of both the start of injection and the amount of exhaust gas recirculation, in order to evaluate further degrees of freedom in the optimisation of the engine settings. Results show that the consideration of the engine noise together with both performance and emissions, reduces dramatically the margin of variation of the combustion settings, limiting therefore the operation range of the engine.
\end{abstract}

Keywords: PCCI combustion, Diesel engines, Combustion noise, Pollutant emissions, gasoline/Diesel blends

${ }^{*}$ Corresponding author. Tel.: +34963877650 , fax: +34963877659 .

Email address: abroatch@mot.upv.es (A. Broatch) 


\section{Introduction}

Improvements in performance, driveability and comfort, together with their low fuel consumption, have placed Diesel engines as the most widely used power-plant in both heavy and light duty vehicles [1]. Along the years, Diesel engines have been subjected to quite restrictive emissions regulations which have forced manufacturers to incorporate new solutions, thus achieving a high standing engine in comparison with the gasoline engine [2]. Despite being regarded as an environmentally friendly engine due to its low consumption and the consequent low carbon dioxide $\left(\mathrm{CO}_{2}\right)$ emission levels, the Diesel engine is not free from drawbacks. In particular, it exhibits a high level of pollutant emissions, most notably nitrous oxides $\left(\mathrm{NO}_{x}\right)$ and soot, mainly because of the poor control achievable on its combustion process. Currently, this is the greatest challenge of Diesel engines if it must comply with the emission standards in the near future. In order to face this difficulty, active and passive solutions have been explored in the last years. Among the active solutions, those advanced concepts promoting a low-temperature combustion have provided the most encouraging results for pollutant formation control [3].

Such a reduction in the combustion temperature can be achieved by means of either homogeneous or premixed charge compression ignition concepts (HCCI and PCCI) [4]. In these concepts, soot formation is controlled by promoting a premixed combustion while the $\mathrm{NO}_{x}$ can be simultaneously controlled by using a large amount of exhaust gas recirculation (EGR) [5]. In spite of such benefits, these new combustion concepts are limited to low load operation due to the complex combustion control required [6]. Additionally, as a consequence of the high rates of heat release produced, excessively high rates of pressure rise are expected and consequently unacceptable noise levels might be emitted by the engine [7].

The premixed combustion can be promoted by using simultaneously higher EGR rates and fuels with high volatility. Large amounts of EGR in the induced charge reduce the oxygen content inside the cylinder, so that the combustion efficiency can be deteriorated and hence both unburned hydrocarbon (UHC) and carbon monoxide (CO) emissions and fuel consumption can be increased [8]. In order to avoid the negative effect of using high EGR rates, fuels with a low cetane number $(\mathrm{CN})$ and high volatility are a good alternative [9]. Since these fuels are more resistant to auto-ignition, a better fuel-air mixing rate can be achieved before the combustion starts [10]. This feature provides additional degrees of freedom when deciding the EGR rate that allows improving the trade-off between engine emissions and fuel economy [11].

In order to operate with premixed combustion, Diesel engines can be fueled with methanol, ethanol, natural gas, biogas, hydrogen or gasoline/Diesel (G/D) blends [12]. Some investigations have revealed that the use of gasoline in Diesel engines permits a better control of the combustion process that allows for the simultaneous reduction of $\mathrm{NO}_{x}$ and soot emissions [13] while torque values higher than those achievable with standard Diesel fuel are obtained. The high volatility of gasoline facilitates the fuel evaporation and improves the fuel-air mixing, so that a homogeneous charge formation is feasible with such a fuel [14]. Additionally, a longer ignition delay (ID) is expected with gasoline due to its low $\mathrm{CN}$, allowing more time to increase the mixing quality before autoignition. However, since an excessive ID could result in an inefficient heat-to-work conversion process, the determination of the suitable proportion of gasoline in the blend is of crucial importance to avoid any penalties in engine performance [15].

Due to the low flammability of the gasoline when higher EGR rates are used, it is very difficult to promote the combustion at low loads, this drawback being magnified when the engine operates at cold conditions [16]. In those conditions, an increase of UHC and CO emissions and of the rate of heat release are expected [17]. The lower viscosity of G/D blends also affects the fuel injection system (FIS). In comparison with a standard FIS, a larger injection pump is required and higher leakages are also expected. Therefore, the fuel delivery must be reduced and consequently the engine power decreases [18].

In particular, PCCI combustion is intrinsically noisy precisely because of the premixed combustion phase, in which intense rates of pressure change are produced [19]. Engine noise is originated by the contribution of both pressure and mechanical forces produced during combustion which cause the vibration of the block. Pressure forces are caused by the abrupt rise of pressure occurring in the combustion chamber at the start of combustion, while mechanical forces are induced by combustion itself [20]. For this reason, at certain operating conditions both contributions are coupled [21]. In addition, the bowl geometry also plays an important role in engine noise control, since it has a noticeable influence on the development of resonant pressure fluctuations, which are induced by the ignition characteristics [22]. Regarding this, Diesel engine noise is highly dependent on any parameter that directly or indirectly affects the characteristics of the combustion process [23]. In particular, previous investigations have shown the sensitivity of 
Diesel combustion noise to injection settings [24] and to the fuel used [25].

In this paper, the suitability of G/D blends for improving the trade-off between pollutant emissions, combustion noise and fuel economy of automotive Diesel engines operating under PCCI combustion concept is analyzed. With this aim, an experimental study on a light-duty DI Diesel engine operating at conditions for which such a concept is most suitable was performed. The effect on the engine parameters mentioned above of two fuel blends with different gasoline concentrations was evaluated by comparison with standard Diesel fuel. The metrics obtained from the decomposition of the in-cylinder pressure signal were used to evaluate both the objective [26] and subjective [27] aspects of combustion noise.

The methods and materials used in this study are presented in Section 2, where the suitability of the variables considered for achieving the objectives of the study is justified. In Section 3, the experimental configuration and the diagnostic technique used in order to predict the combustion noise are described. The results obtained are discussed in Section 4 in three separate subsections focusing on pollutant emissions, combustion noise and engine performance, respectively. In addition, the trade-off between these engine parameters is analyzed in Section 5. Finally, Section 6 summarizes the most relevant conclusions extracted from the work.

\section{Materials and methods}

A multi-cylinder compression-ignited (CI) automotive engine running at $1500 \mathrm{rpm}$ and low load (38 Nm / 0.298 $\mathrm{MPa}$ of brake mean effective pressure -bmep) was used. This operating condition was chosen due to the following reasons:

1. The engine noise is unacceptable when it operates under conventional Diesel combustion.

2. It is a frequent condition (about $13 \%$ of total time) during a standard MVEG (Motor Vehicle Emissions Group) test cycle.

3. At this condition the PCCI combustion concept offers most of its potential.

Taking into consideration the results obtained by the authors in previous studies on PCCI combustion [19], the intake temperature was set to $45^{\circ} \mathrm{C}$ while the temperatures of the rest of the engine fluids were kept constant at the nominal values. All the tests were performed keeping constant the fuel quantity, considering a single injection of 10 $\mathrm{mg} /$ stroke at $80 \mathrm{MPa}$ of injection pressure.

In order to analyse the impact of G/D blended fuels on PCCI combustion, three engine settings were chosen to define the test plan:

- Six values of injection timing advanced enough so as to run the engine under PCCI combustion but controlling the wall-impingement of the fuel in order to ensure that any lack of torque was not caused by this phenomenon.

- Three levels $(10 \%, 12 \%$ and $14.5 \%)$ of oxygen concentration at the intake $\left(\left[\mathrm{O}_{2}\right]_{\mathrm{IN}}\right)$ which could be used for PCCI combustion.

- Three different fuels: standard Diesel and two G/D blends. The percentages of volumetric concentrations of gasoline in the G/D blended fuels were $25 \%$ and $50 \%$. According to other reported studies, these concentrations ensure suitable combustion stability when operating with the PCCI combustion concept [15]. A fuel lubricity additive $(500 \mathrm{ppm})$ was included also in the G/D blended fuel in order to avoid any damages to the FIS.

The ranges of change of these variables allow to dispose a wide sample of PCCI combustion issues. The test matrix resulting from the above considerations is summarized in Table 1, while the main physical properties of the fuels used in the tests are given in Table 2.

After each test, the fuel line was emptied in order to avoid any effect from the fuel used in previous tests. The fuel tank was refilled with the other fuel, and then the engine was run under conventional Diesel combustion at high load as long as necessary before any new measurements were performed. 


\section{Experimental setup}

The same experimental configuration used by the authors in previous studies was used also in this investigation $[19,24]$. The tests were performed on a test bench composed of an 1.61 four-cylinder Euro IV turbocharged direct injection (DI) Diesel engine directly coupled to an asynchronous dynamometer. The production EGR system of the engine was modified in order to achieve the temperature and oxygen concentrations in the intake required to run the engine under PCCI combustion. With this aim an almost $40 \%$ larger EGR cooler was used together with an external cooling system, so that an accurate control of intake temperature was ensured. The main specifications of the engine and the injector are summarized in Table 3.

Even though the engine noise was predicted by means of the procedure presented in Section 4 , engine noise measurements in free field conditions were also performed in order to check, at any time of the work, the reliability of the procedure used for predicting the noise level.

With the purpose of controlling and characterizing the operation of the engine the following instrumentation were used:

- K type thermocouples for measuring the temperature of all the engine fluids.

- A HORIBA MEXA-720 portable analyzer was used to measure the $\mathrm{NO}_{x}$ emissions, the $\mathrm{O}_{2}$ concentration in the exhaust, the equivalence ratio and the excess air ratio $(\lambda)$.

- The $\mathrm{O}_{2}$ concentration in the intake air was measured with a lambda probe placed in the intake manifold.

- An AVL 451S filter-type smoke meter was used for measuring the filter smoke number (FSN). The correlation proposed by Christian et al. [28] was used to estimate the soot emission from FSN measurements.

- Kistler 6055Bsp glow-plug piezoelectric sensors were used to measure the pressure trace in each cylinder with a sampling frequency of $50 \mathrm{kHz}$, so that a bandwidth similar to the human domain of hearing $(20 \mathrm{~Hz}-20 \mathrm{kHz})$ was available.

The accuracy of the instrumentation used is summarized in Table 4. In each test, in-cylinder pressure traces of 50 consecutive cycles were recorded. In order to modify the engine settings accordingly to the method described above, an open ECU (Engine Control Unit) was used. Additional details of the experimental configuration can be found in [19].

\section{Combustion noise assessment}

As in previous studies, the objective and subjective aspects of combustion noise were characterized making use of the predictive procedures developed by Torregrosa et al. [26] and Payri et al. [27], respectively. Both procedures are based on the identification of cause-effect relations between the source and the radiated noise. With this approach, both the overall noise $(\mathrm{ON})$ and its sound quality, which is quantified by a mark, are predicted from the in-cylinder pressure decomposition [21].

In these procedures, the in-cylinder pressure signal is decomposed into three sub-signals that represent the main phenomena which characterize the combustion process. These sub-signals are:

- The compression-expansion sub-signal, that represents the increment and the reduction of in-cylinder pressure due to the volume variation experienced by the charge as a result of the piston motion.

- The combustion sub-signal, that characterizes the combustion process. The temporal evolution of the in-cylinder pressure during combustion is strongly influenced by the rate of heat release which, in turn, is affected by the injection settings.

- The resonance sub-signal, that characterizes the oscillations of the burned gas inside the combustion chamber caused by the abrupt pressure rise rates [29]. 
The overall level and the sound quality of combustion noise were predicted by empirical correlations containing operation and combustion indicators. Torregrosa et al. [26] found that the overall noise is highly correlated with an operation indicator, $I_{n}$, that quantifies the contribution of engine speed to noise, and two combustion indicators, $I_{1}$ and $I_{2}$, which are the contributions of the fuel burning velocity and of the resonance inside the combustion chamber [22], respectively. The correlation for the overall level is represented by the following expression:

$$
\mathrm{ON}=C_{0}+C_{n} I_{n}+C_{1} I_{1}+C_{2} I_{2}+\epsilon_{\mathrm{ON}}
$$

In this equation, $C_{i}$ are coefficients dependent on the engine family and size, $\epsilon$ is the error and the indicators are defined by the following equations:

$$
\begin{gathered}
I_{n}=\log \left[\frac{n}{n_{\text {idle }}}\right] \\
I_{1}=\frac{n}{n_{\text {idle }}}\left[\frac{(\mathrm{d} p / \mathrm{d} t)_{\text {comb }}^{\max 1}+(\mathrm{d} p / \mathrm{d} t)_{\mathrm{comb}}^{\max 2}}{(\mathrm{~d} p / \mathrm{d} t)_{\mathrm{comp}}^{\max }}\right] \\
I_{2}=\log \left[E_{0} \frac{E_{\text {res }}}{E_{\text {comp }}}\right]
\end{gathered}
$$

where $n$ and $n_{\text {idle }}$ are the actual and idle speed, respectively; $(\mathrm{d} p / \mathrm{d} t)_{\text {comb }}^{\max 1}$ and $(\mathrm{d} p / \mathrm{d} t)_{\text {comb }}^{\max 2}$ represent the two highest peaks of the pressure derivative during combustion, $(\mathrm{d} p / \mathrm{d} t)_{\mathrm{comp}}^{\max }$ is the peak value of the pressure derivative corresponding to the compression-expansion component, $E_{0}$ is a scaling factor, $E_{\text {res }}$ is the signal energy of the resonance and $E_{\text {comp }}$ is the signal energy of the compression-expansion signal.

In addition, Payri et al. [27] verified that the combustion indicators defined above were highly correlated also with the sound quality of combustion noise. Sound quality is quantified by a mark ranging from 0 to 10 which represents the satisfaction degree of an average customer. The correlation proposed by Payri et al. is the following:

$$
\text { Mark }=10-c_{1} I_{1}-c_{2} I_{2}+\epsilon_{\text {Mark }}
$$

Here $c_{i}$ coefficients are also characteristic of the engine family and size, but their values are different from those of Equation (1).

\section{Results and discussion}

In this section the results in terms of pollutant emissions, combustion noise and engine performance will be discussed in detail. With this purpose, the results obtained with the Diesel standard fuel and the G/D blends under PCCI combustion will be compared with those obtained under conventional Diesel combustion. Then, the reference $\mathrm{NO}_{x}$ and soot emission levels are $80 \mathrm{ppm}$ and $20 \mathrm{mg}$ particles $/ \mathrm{m}^{3}$ respectively, while the bmep is $0.298 \mathrm{MPa}$. Regarding combustion noise, a mark equal to 7 was considered as the acceptable comfort threshold of an average customer [27].

\subsection{Pollutant emissions and engine performance}

The analysis of pollutant emissions was focused on $\mathrm{NO}_{x}$ and soot levels, since the main advantage provided by the PCCI combustion concept is precisely the reduction of these pollutants.

Figure 1 shows the trends followed by $\mathrm{NO}_{x}$ and soot emissions. In general, the best $\mathrm{NO}_{x}$-Soot trade-offs are consistently obtained at advanced SOE (start of energizing), where the combustion switches from the conventional Diesel combustion concept to the PCCI combustion concept, thus confirming its potential to control both pollutants simultaneously in production engines. However, moderate-to-high levels of EGR are mandatory to control mixture reactivity and $\mathrm{NO}_{x}$ emissions due to the local mixture heterogeneities with zones in stoichiometric conditions. In these zones the maximum combustion temperatures are still high despite fuel premixing. This is implicitly corroborated by the reduction in $\mathrm{NO}_{x}$ attainable by advancing the SOE, which extends the ignition delay (ID) as shown in Fig. 2, so there is more time available for decreasing the local air/fuel ratios before the onset of the combustion process [30]. The impact of $\mathrm{G} / \mathrm{D}$ blends on $\mathrm{NO}_{x}$ emissions is moderate, since the adiabatic flame temperatures of gasoline 
and Diesel are quite similar, and thus the only benefit is a consequence of the longer ID observed in Fig. 2 as the gasoline fuel fraction increases [31]. This retards the onset of combustion thus producing lower maximum pressures and temperatures during the combustion process.

The soot emission trends observed in Fig. 1 corroborate the transition from conventional Diesel combustion to PCCI combustion as SOE is advanced. Particularly for medium-to-low $\left[\mathrm{O}_{2}\right]_{\mathrm{IN}}$ soot emissions initially increase but if SOE is further advanced they sharply decrease down to very low levels. This sharp soot emissions reduction at early SOE is caused by the longer ID and mixing time availability, resulting in lower local equivalence ratios below the soot formation limit, which is known to be around 2.5 to 2 [32]. Figure 1 also confirms the positive effect of increasing the gasoline proportion on soot emissions, which is directly related to its impact on ID and mixing time shown in Fig. 2. The physical and chemical properties of G/D blends, such as low initial boiling point and high octane number [33], contribute to the extension of the premixed combustion phase, due to a higher ID [34]. A parameter that allows to justify the observed reduction in soot emissions is the ratio between ID and the injection time (IT), which describes the mixing time availability in relation to the injection duration, so that the higher this parameter is, the lower are the maximum local equivalence ratio and consequently the lower the soot formation. As observed in Fig. 2, this parameter increases by decreasing $\left[\mathrm{O}_{2}\right]_{\mathrm{IN}}$ (lowest effect), advancing the $\mathrm{SOE}$ and also increasing the gasoline fuel fraction. Despite that the trigger level of ID/IT required to operate in PCCI combustion conditions depends on different factors, including the engine hardware configuration, according to the results obtained its value should be well above 3, which gives a first idea about the suitable SOE range for implementing this advanced combustion concept.

As a final remark, it has been proven that blending gasoline fuel with the conventional Diesel fuel in compression ignition engines is an attractive alternative to make the implementation of the PCCI combustion concept easier, since these blends require less EGR and SOE advance to achieve extremely low $\mathrm{NO}_{x}$ and soot emissions.

\subsection{Combustion noise}

Figure 3 shows the results corresponding to the noise characterization of the engine at all the conditions considered. In a first view, the results evidence that the overall noise is inversely proportional to the mark that represent its sound quality. In addition, it is observed that the noise is increased as the injection timing is delayed and, as expected, there is a great impact of the oxygen concentration in the intake on the noise issues. For all the injection timings and fuels tested, combustion noise is improved when the oxygen concentration is reduced.

Regarding the subjective perception of engine noise, Fig. 3b, 3d and 3f show that the level of acceptance can be surpassed when the oxygen concentration is lower than $12 \%$ and for a narrow range of advanced injections, which depends on the fuel. Since advanced injections could lead to a penalty in the bmep, these conditions will be the object of a thorough discussion in the following sections.

Concerning the effect of the fuel on the combustion noise, the results are not conclusive altogether, except for the mark estimated for the lowest $\left[\mathrm{O}_{2}\right]_{\mathrm{IN}}$ considered, for which it is clear that the sound quality of engine noise is enhanced when the G50 blend of fuel is used.

The estimated values of the combustion indicators which characterize the combustion noise source are shown in Fig. 4. The plots show that the indicator $I_{1}$, that is related to the fuel burning velocity, increases if either the oxygen concentration is increased or the injection is delayed. In the same way, the energy of the resonance (characterized by indicator $I_{2}$ ) increases when $\left[\mathrm{O}_{2}\right]_{\mathrm{IN}}$ also increases. Fig. 4b shows that, with the highest $\left[\mathrm{O}_{2}\right]_{\mathrm{IN}}$, the energy of the resonance is scarcely sensitive to the injection timing and therefore, taking into account the results of Fig. 3a and 4a, one can conclude that the indicator $I_{1}$ strongly contributes to the engine noise. Moreover, Fig. $4 \mathrm{~d}$ and $4 \mathrm{f}$ show that $I_{2}$ increases as the injection timing is delayed when EGR is used and consequently the oxygen concentration is reduced.

In the next sub-sections a detailed analysis of the sensitivity of combustion noise to the combustion parameters and fuels considered in the investigation is presented.

\subsubsection{Sensitivity to start of injection}

Figure 5 shows the in-cylinder pressure trace and the evolution of the pressure derivative of the combustion signal -which is related to the rate of fuel burning- obtained for different injection timings when the engine operates with an $\left[\mathrm{O}_{2}\right]_{\mathrm{IN}}$ of $10 \%$ and is fueled with standard Diesel. In-cylinder pressure traces of Fig. 4f and 5a show that the amplitude of the high-frequency pressure oscillations is increased as the injection timing is delayed. The increase of the amplitude of this oscillations is mainly caused by the increase of the pressure rise rate, which is associated 
with the fuel burning velocity. Indeed, Fig. $5 \mathrm{~b}$ shows that the pressure derivative peaks increase as the injection is delayed. Due to the contribution of both effects, the increase of the energy of resonance and the rate of fuel burned, the combustion noise is deteriorated as shown in Fig. 3f.

\subsubsection{Sensitivity to oxygen concentration in the intake}

Previous results have shown that both pollutant emissions and combustion noise are strongly affected by the oxygen concentration in the intake. Reducing $\left[\mathrm{O}_{2}\right]_{\mathrm{IN}}$, a longer ignition delay can be achieved and consequently the combustion is shifted towards the top dead center. In this situation, the fuel burning velocity is reduced, and therefore both the rate of pressure change and the intensity of the resonance in the combustion chamber are reduced. This fact is evidenced by the results shown in Fig. 6, where the in-cylinder pressure traces and the pressure derivative of the combustion signals for the engine operating with an injection timing of - 30 crank angle degree after Top Dead Center (cad aTDC), standard Diesel fuel and three oxygen concentrations are depicted. A less abrupt combustion is promoted as the concentration is reduced and the sound quality of the combustion noise is thus enhanced.

\subsubsection{Sensitivity to the fuel}

The results shown in Fig. 3 evidence that the effect on combustion noise of the fuel burned starts to be apparent for low values of oxygen concentration in the intake. In particular, the most relevant differences were observed when this concentration is as low as 10\%. This effect is made clear in the plots in Fig. 7, which show the pressure and pressure derivative evolutions inside the cylinder for an SOE of -34 cad aTDC and the three fuels considered. These plots clearly show that the peak value of the rate of burned fuel decreases as the volumetric concentration of gasoline in the G/D blend of fuel increases, whence less knock can be noticed in the in-cylinder pressure traces. As in the previous analysis, these conditions lead to a smoother combustion process with which a better subjective perception of the noise emitted by the engine can be achieved.

Up to this point, the results lead to conclude that the best strategies in order to improve the PCCI combustion in terms of pollutant emissions reduction and noise improvement is obtained by employing $10 \%$ of $\left[\mathrm{O}_{2}\right]_{\mathrm{IN}}$ and G50 blend. In the following section, the performance of the engine using such strategies will be analyzed in detail.

\subsection{Engine performance}

With respect to engine performance, Fig. 8 confirms that the bmep progressively decreases when advancing SOE for all fuel blends; however, the combustion phasing traced by the crank angle degree at which $50 \%$ of the total heat release occurs (CA50) does not follow a clear pattern. Thus, the negative impact of advancing SOE on bmep is expected to be basically caused by the higher $\mathrm{CO}$ and UHC emissions resulting from increasing the over-lean regions and liquid fuel impingement onto the combustion chamber walls.

An interesting trend is observed by comparing the results using gasoline/Diesel blends with those obtained with standard Diesel fuel. The increment seen in bmep is caused mainly by the better combustion phasing, as it is significantly retarded as a result of the decreased reactivity provided by the blended fuel. In addition, the longer ignition delay and mixing time enhances the homogeneity of the mixture, which has also a positive impact on bmep [35]. Another aspect helping to increase bmep is the less liquid fuel wall impingement expected for the blended fuel as a result of the higher volatility of gasoline compared to Diesel fuel, which would result in lower UHC emissions.

\section{Assessment of trade-offs between parameters}

A global analysis of the results previously reported is performed in this section in order to identify all the relevant tendencies, by using the contour plots shown in Fig. 9 with injection timing and $\left[\mathrm{O}_{2}\right]_{\mathrm{IN}}$ as axes.

The left column shows the contour corresponding to $\mathrm{NO}_{x}$ and soot levels, where the white zone represents the range in which any of the two pollutants is above the target limits. According to these results, the optimum zone (green) from the point of view of pollutant emissions is extended using gasoline/Diesel blends, especially at low $\left[\mathrm{O}_{2}\right]_{\mathrm{IN}}$ conditions.

Subsequently, if pollutant emissions results are combined with engine bmep results, as show in the center column, the best zones for all fuels are those where $\left[\mathrm{O}_{2}\right]_{\mathrm{IN}}$ is lower than $12 \%$ and SOE ranges between - 30 and -18 cad aTDC. In addition, the range with suitable bmep levels is extended when using gasoline/Diesel blends. 
The right column confirms that including the combustion noise target reduces strongly the optimum range of operation. Contrarily to the bmep, for which the optimum range was located towards the right of the contour map, the combustion noise pattern is completely opposite. The sound quality improves for very advanced SOE and $\left[\mathrm{O}_{2}\right]_{\mathrm{IN}}$ below to $11 \%$, that is, the optimal range is found towards the bottom-left corner of the map. For Diesel and G25 gasoline/Diesel blend fuels, no intersection is observed between the acceptable sound quality target -represented by a mark of 7- and the bmep target. In fact, a very limited region fulfilling all targets is observed only for the G50 gasoline/Diesel blend when the SOE is approximately -30 cad aTDC and $\left[\mathrm{O}_{2}\right]_{\mathrm{IN}}$ is $10 \%$.

These results confirm that the trade-off between combustion noise and engine bmep is a key restrictive factor for the PCCI combustion concept, in which low $\mathrm{NO}_{x}$ and soot levels are produced. Additionally, it has been proven that the use of gasoline/Diesel blends leads to a wider operation range where the PCCI combustion concept provides promising results not only concerning pollutant emissions, but also considering thermal efficiency and combustion noise.

\section{Conclusions}

There is no doubt about the great potential of the PCCI combustion concept in order to reduce $\mathrm{NO}_{x}$ and particulate emissions of Diesel engines. However, these benefits are counteracted by the deterioration of engine noise and even of performance. In this work, the suitability of gasoline/Diesel blends for addressing these issues was analyzed. The use of such blends reduces liquid impingement onto the combustion chamber walls, enhances the air-fuel mixing process and provides a better combustion phasing, so that engine performance improves when compared to the results obtained using standard Diesel fuel. Additionally, for a given oxygen concentration at the intake, the lower cetane number of these blends permits extending the ID, so that a less abrupt combustion is promoted and consequently the engine noise level decreases. Therefore, these properties allow for considering engine settings keeping the EGR rate at levels attainable with current production EGR systems.

Regarding pollutant emissions, the results show that keeping constant both the injected fuel mass and the injection pressure, $\mathrm{NO}_{x}$ formation is mainly affected by the oxygen concentration of the charge, while soot formation is clearly dominated by the volumetric concentration of gasoline in the blend. Moreover, independently of the SOE, the best $\mathrm{NO}_{x}$-soot trade-off was obtained with $\left[\mathrm{O}_{2}\right]_{\mathrm{IN}}$ of $10 \%$ and a gasoline concentration of $50 \%$ in the fuel blend.

The results also show that combustion noise is more sensitive to $\left[\mathrm{O}_{2}\right]_{\mathrm{IN}}$ variations than to the fuel used. In addition, it appears that there exists a threshold level of $\left[\mathrm{O}_{2}\right]_{\mathrm{IN}}$, between $12 \%$ and $10 \%$, above which the contribution of the gasoline content in the blend to the improvement of the sound quality of combustion noise is more apparent. Again, the noise comfort limit (Mark=7) is surpassed when the most advanced injection settings (between -38 and -30 cad aTDC) are used together with the lowest oxygen concentration of the charge at the intake $\left(\left[\mathrm{O}_{2}\right]_{\mathrm{IN}}=10 \%\right)$. However, a loss of bmep has been observed at these advanced injection conditions, even though this effect can be partly tackled by using gasoline/Diesel blends as fuel.

In summary, this investigation confirms that gasoline/Diesel blends are suitable fuels in order to preserve the potential of PCCI combustion for reducing pollutant emissions by controlling its negative impact on engine efficiency. Nevertheless, the consideration of engine noise together with such emissions-performance trade-off, reduces dramatically the degrees of freedom for the optimization of engine settings, since the optimal solution appears to be a single combination of $\left[\mathrm{O}_{2}\right]_{\mathrm{IN}}, \mathrm{SOE}$ and fuel composition.

\section{Acknowledgements}

The equipment used in this work has been partially supported by the Spanish Ministerio de Economía y Competitividad through grant no DPI2015-70464-R and by FEDER project funds "Dotación de infraestructuras científico técnicas para el Centro Integral de Mejora Energética y Medioambiental de Sistemas de Transporte (CiMeT), (FEDERICTS-2012-06)" framed in the operational program of unique scientific and technical infrastructure of the Spanish Ministerio de Economía y Competitividad.

J. Gomez-Soriano is partially supported through contract FPI-S2-2016-1353 of the "Programa de Apoyo para la Investigacin y Desarrollo (PAID-01-16)" of Universitat Politcnica de Valncia.

The authors also wish to thank Mr. Bernardo Planells for his inestimable assistance during the experimental campaign. 
[1] ACEA. European automobile manufacturers association. Economic and Market Report: EU Automotive Industry, Quarter 12016 ; 2016.

[2] Benajes J, Molina S, Novella R, Belarte E. Evaluation of massive exhaust gas recirculation and Miller cycle strategies for mixing-controlled low temperature combustion in a heavy duty Diesel engine. Energy 2014;71:355-66.

[3] Hountalas DT, Mavropoulos GC, Binder KB. Effect of exhaust gas recirculation (EGR) temperature for various EGR rates on heavy duty DI Diesel engine performance and emissions. Energy 2008;33(2):272-83.

[4] Sharma TK, Rao GAP, Murthy KM. Effective reduction of NOx emissions of a HCCI (Homogeneous charge compression ignition) engine by enhanced rate of heat transfer under varying conditions of operation. Energy 2015;93(2):2102-15.

[5] W.L. Hardy, R.D. Reitz, A study of the effects of high EGR, high equivalence ratio, and mixing time on emissions levels in a heavy-duty Diesel engine for PCCI combustion. SAE Technical Paper, 2006-01-0026.

[6] Keeler B, Shayler PJ. Constraints on fuel injection and EGR strategies for Diesel PCCI-type combustion. SAE paper 2008-01-1327. Warrendale, PA: Society of Automotive Engineers Inc.; 2008.

[7] A. Broatch, X. Margot, R. Novella, J. Gomez-Soriano, Combustion noise analysis of partially premixed combustion concept using gasoline fuel in a 2-stroke engine. Energy 2016;107:612-624.

[8] Choi S, Park W, Lee S, Min K, Choi H. Methods for in-cylinder EGR stratification and its effects on combustion and emission characteristics in a Diesel engine. Energy 2011;36(12):6948-59.

[9] Kerschgens B, Vanegas A, Pitsch H. Numerical assessment of emission sources for a modified Diesel engine running in PCCI mode on a mixture of gasoline and Diesel. SAE paper 2011-24-0014. Warrendale, PA: Society of Automotive Engineers Inc.; 2011.

[10] Han D, Ickes AM, Assanis DN, Huang Z, Bohac SV. Attainment and load extension of high-efficiency premixed low-temperature combustion with Dieseline in a compression ignition engine. Energy Fuels 2010;24:3517-25.

[11] Kalghatgi G, Hildingsson L, Harrison A, Johansson B. Low $\mathrm{NO}_{x}$, low smoke operation of a Diesel engine using premixed enough compression ignition: Effects of fuel autoignition quality, volatility and aromatic content. THIESEL 2010 Conference on Thermo- and Fluid Dynamic Processes in Diesel Engines.

[12] Valentino G, Corcione F, Iannuzzi S, Serra S. Effects of premixed low temperature combustion of fuel blends with high resistance to autoignition on performances and emissions in a high speed Diesel engine. SAE paper 2011-24-0049. Warrendale, PA: Society of Automotive Engineers Inc.; 2011.

[13] Kalghatgi G, Hildingsson L, Johansson B. Low $\mathrm{NO}_{x}$ and low smoke operation of a Diesel engine using gasoline like fuels. J Eng Gas Turb Power 2010;132(9):092803.

[14] Zhong S, Wyszynski ML, Megaritis A, Yap D, Xu H. Experimental investigation into HCCI combustion using gasoline and Diesel blended fuels. SAE paper 2005-01-3733. Warrendale, PA: Society of Automotive Engineers Inc.; 2005.

[15] Sahin Z. Experimental and theoretical investigation of the effects of gasoline blends on single-cylinder Diesel engine performance and exhaust emissions. Energy Fuels 2008;22(5):3201-12.

[16] Dijkstra R, Di Blasio G, Boot M, Beatrice C, Bertoli C. Assessment of the effect of low cetane number fuels on a light duty CI engine: Preliminary experimental characterization in PCCI operating condition. SAE paper 2011-24-0053. Warrendale, PA: Society of Automotive Engineers Inc.; 2011.

[17] Kalghatgi GT, Hildingsson L, Harrison AJ, Johansson B. Surrogate fuels for premixed combustion in compression ignition engines. Int J Engine Res 2011;12(5):452-65.

[18] Shi Y, Reitz RD. Optimization of a heavy-duty compression-ignition engine fueled with Diesel and gasoline-like fuels. Fuel 2010;89(11):3416-30.

[19] Torregrosa AJ, Broatch A, Novella R, Mónico LF. Suitability analysis of advanced Diesel combustion concepts for emissions and noise control. Energy 2011;36(2):825-38.

[20] Pruvost L, Leclre Q, Parizet E. Diesel engine combustion and mechanical noise separation using an improved sprectrofilter. Mech Syst Sig Process 2009;23(7):2072-87.

[21] Payri F, Broatch A, Tormos B, Marant V. New methodology for in-cylinder pressure analysis in direct injection Diesel engines - application to combustion noise. Meas Sci Technol 2005;16(2):540-7.

[22] Broatch A, Margot X, Gil A, Donayre C. Computational study of the sensitivity to ignition characteristics of the resonance in DI Diesel engine combustion chambers. Eng Comput 2007;24(1-2):77-96.

[23] Broatch, A., Margot, X., Novella, R. and Gomez-Soriano, J. Impact of the injector design on the combustion noise of gasoline partially premixed combustion in a 2-stroke engine. Applied Thermal Engineering 2017,119:530-540.

[24] Torregrosa AJ, Broatch A, García A, Mónico LF. Sensitivity of combustion noise and $\mathrm{NO}_{x}$ and soot emissions to pilot injection in PCCI Diesel engines. Appl. Energy 2013;104:149-57.

[25] Torregrosa AJ, Broatch A, Pla B, Mónico LF. Impact of Fischer-Tropsch and biodiesel fuels on trade-offs between pollutant emissions and combustion noise in Diesel engines. Biomass Bioenergy 2013;52:22-33.

[26] Torregrosa AJ, Broatch A, Martín J, Monelletta L. Combustion noise level assessment in direct injection Diesel engines by means of incylinder pressure components. Meas Sci Technol 2007;18(7):2131-42.

[27] Payri F, Torregrosa AJ, Broatch A, Monelletta L. Sound quality assessment of Diesel combustion noise using in-cylinder pressure components. Meas. Sci. Technol 2009;20:015107.

[28] Christian VR, Knopf F, Jaschek A, Schindler W. Eine neue Me $\beta$ methodik der Bosch-Zahl mit erhörter Empfindlichkeit, MTZ Motortech 1993;54:16-22.

[29] Torregrosa AJ, Broatch A, Margot X, Marant V. Beaugé Y. Combustion chamber resonances in direct injection automotive Diesel engines: A Numerical Approach. Int J Engine Res 2004;5(1):83-91.

[30] Corcione F, Valentino G, tornatore C, Merola S, Marchitto. Optical investigation of premixed low-temperature combustion of lighter fuel blends in compression ignition engines. SAE paper 2011-24-0045. Warrendale, PA: Society of Automotive Engineers Inc.; 2011.

[31] Han D, Ickes AM, Bohac SV, Huang Z, Assanis DN. Premixed low-temperature combustion of blends of Diesel and gasoline in a high speed compression ignition engine. P Combust Inst 2011;33(2):3039-46.

[32] Kamimoto T, Bae M. High combustion temperature for the reduction of particulate in Diesel engines. SAE Paper 880423. Warrendale, PA: 
Society of Automotive Engineers Inc.; 1988.

378 [33] Kim DS, Lee CS. Improved emission characteristics of HCCI engine by various premixed fuels and cooled EGR. Fuel 2006;85(5-6):695-704.

[34] Weall A, Collings N. Gasoline fuelled partially premixed compression ignition in a light duty multi cylinder engine: A study of low load and low speed operation. SAE paper 2009-01-1791. Warrendale, PA: Society of Automotive Engineers Inc.; 2009.

[35] Kalghatgi GT, Risberg P, Angstrom HE. Partially pre-mixed auto-ignition of gasoline to attain low smoke and low $\mathrm{NO}_{x}$ at high load in a compression ignition engine and comparison with a Diesel fuel. SAE paper 2007-01-0006. Warrendale, PA: Society of Automotive Engineers Inc.; 2007. 

Fig. 1 Effect of injection timing, oxygen concentration and fuel on pollutant emissions: $\mathrm{NO}_{x}$ (left column) and soot (right column).

387 Fig. 2 Effect of injection timing, oxygen concentration and fuel on: ID (left column) and ID/IT (right column). Fig. 3 Effect of injection timing, oxygen concentration and fuel on engine noise: ON (left column) and Mark (right column).

Fig. 4 Effect of injection timing, oxygen concentration and fuel on combustion indicators: $I_{1}$ (left column) and $I_{2}$ 391 (right column).

Fig. 5 Effect of injection timing on in-cylinder pressure (a) and pressure derivative of the combustion signal (b) for Diesel standard and $\left[\mathrm{O}_{2}\right]_{\mathrm{IN}}$ of $10 \%$.

Fig. 6 Effect of the $\left[\mathrm{O}_{2}\right]_{\mathrm{IN}}$ on in-cylinder pressure (a) and pressure derivative of the combustion signal (b) for Diesel standard and SOE of -30 cad aTDC.

Fig. 7 Effect of fuel on in-cylinder pressure (a) and pressure derivative of the combustion signal (b) for $\left[\mathrm{O}_{2}\right]_{\mathrm{IN}}$ of $10 \%$ and SOE of $-34 \mathrm{cad}$ aTDC.

398

Fig. 8 Effect of injection timing and fuel to bmep (a) and CA50 (b) for $\left[\mathrm{O}_{2}\right]_{\mathrm{IN}}$ of $10 \%$. at PCCI combustion with the three types of fuel used: D (top row), G25 (center row) and G50 (bottom row). 
Table 1: Test matrix considered in the study.

\begin{tabular}{cccc}
\hline $\begin{array}{c}\text { Injection pressure } \\
(\mathrm{MPa})\end{array}$ & $\begin{array}{c}{\left[\mathrm{O}_{2}\right]_{\mathrm{IN}}} \\
(\%)\end{array}$ & $\begin{array}{c}\mathrm{SOE} \\
(\mathrm{Deg})\end{array}$ & $\begin{array}{c}\text { Fuel } \\
\text { (in volumetric concentrations) }\end{array}$ \\
\hline \multirow{2}{*}{80} & 10 & -38 to $-18 \mathrm{cad}$ & $\mathrm{D}: 100 \%$ Diesel \\
& 12 & G25: $25 \%$ gasoline $/ 75 \% \mathrm{D}$ \\
& 14.5 & aTDC each 4 & G50: $50 \%$ gasoline / 50\% D \\
\hline
\end{tabular}

Table 2: Properties of fuels used.

\begin{tabular}{ccccc}
\hline $\begin{array}{c}\text { Fuel } \\
\text { (in volumetric concentrations) }\end{array}$ & $\begin{array}{c}\text { Density } \\
15^{\circ} \mathrm{C}\left(\mathrm{kg} / \mathrm{m}^{3}\right)\end{array}$ & $\begin{array}{c}\text { Cetane } \\
\text { index }\end{array}$ & $\begin{array}{c}\text { Viscosity } \\
40^{\circ} \mathrm{C}(\mathrm{cSt})\end{array}$ & $\begin{array}{c}\text { Heating value } \\
\left(\mathrm{MJ} \mathrm{kg}^{-1}\right)\end{array}$ \\
\hline $\mathrm{D}$ & 839.3 & 51.2 & 2.676 & 42.900 \\
$\mathrm{G} 25$ & 814.3 & 36.6 & 1.525 & 43.060 \\
$\mathrm{G} 50$ & 777.5 & 28.3 & 1.031 & 43.250 \\
\hline
\end{tabular}


Table 3: Engine and injector specifications.

\begin{tabular}{lcc}
\hline Engine Type & & $\begin{array}{c}\text { Direct-injection Diesel engine } \\
\text { Cylinders }\end{array}$ \\
Bore & $(\mathrm{mm})$ & in line \\
Stoke & $(\mathrm{mm})$ & 75 \\
Compression ratio & & 88.3 \\
Injector nozzle holes & & $18: 1$ \\
Nozzle holes diameter & $(\mathrm{mm})$ & 6 \\
Spray angle & $(\mathrm{deg})$ & 0.124 \\
\hline
\end{tabular}

404 
Table 4: Accuracy of the instrumentation used.

\begin{tabular}{lll}
\hline Sensor & Variable & Accuracy [\%] \\
\hline Piezoelectric & In-cylinder pressure & 0.4 \\
Thermocouples & Temperature of all fluids & 0.35 \\
Encoder & Engine speed & 0.006 \\
Exhaust gas analyzer & $\mathrm{NO}_{x}$ emissions and $\mathrm{O}_{2}$ concentration & 2 \\
& in the exhaust & \\
Lambda probe & $\mathrm{O}_{2}$ concentration in the intake & 1.81 \\
Smoke meter & FSN & 3 \\
Piezoresistive & Intake and exhaust pressure & 0.65 \\
Torque meter & Torque & 0.1 \\
Fuel mass flow meter & Fuel mass & 0.2 \\
Air mass flow meter & Air mass & 0.12 \\
\hline
\end{tabular}



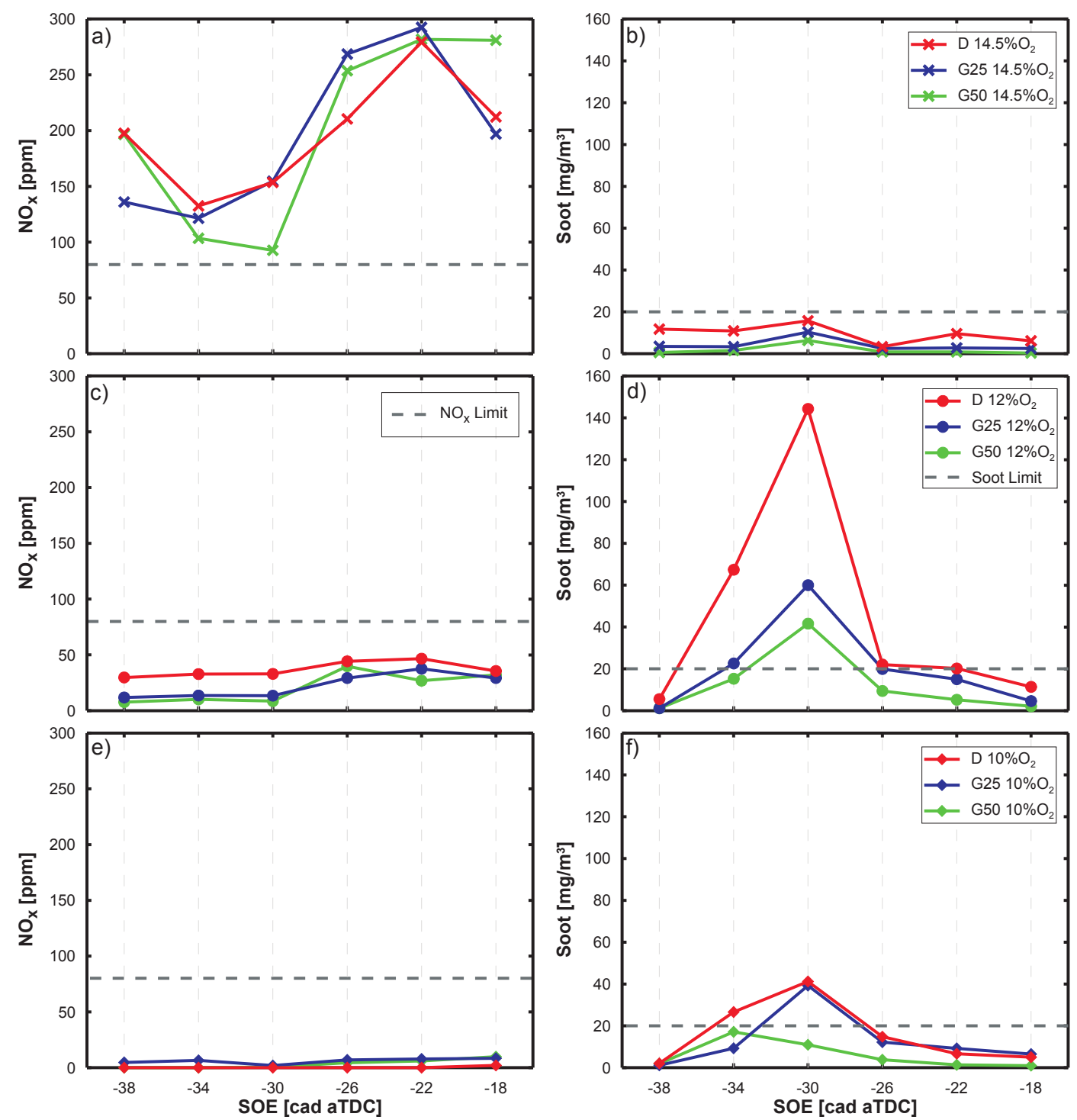

Figure 1: Effect of injection timing, oxygen concentration and fuel on pollutant emissions: $\mathrm{NO}_{x}$ (left column) and soot (right column). 

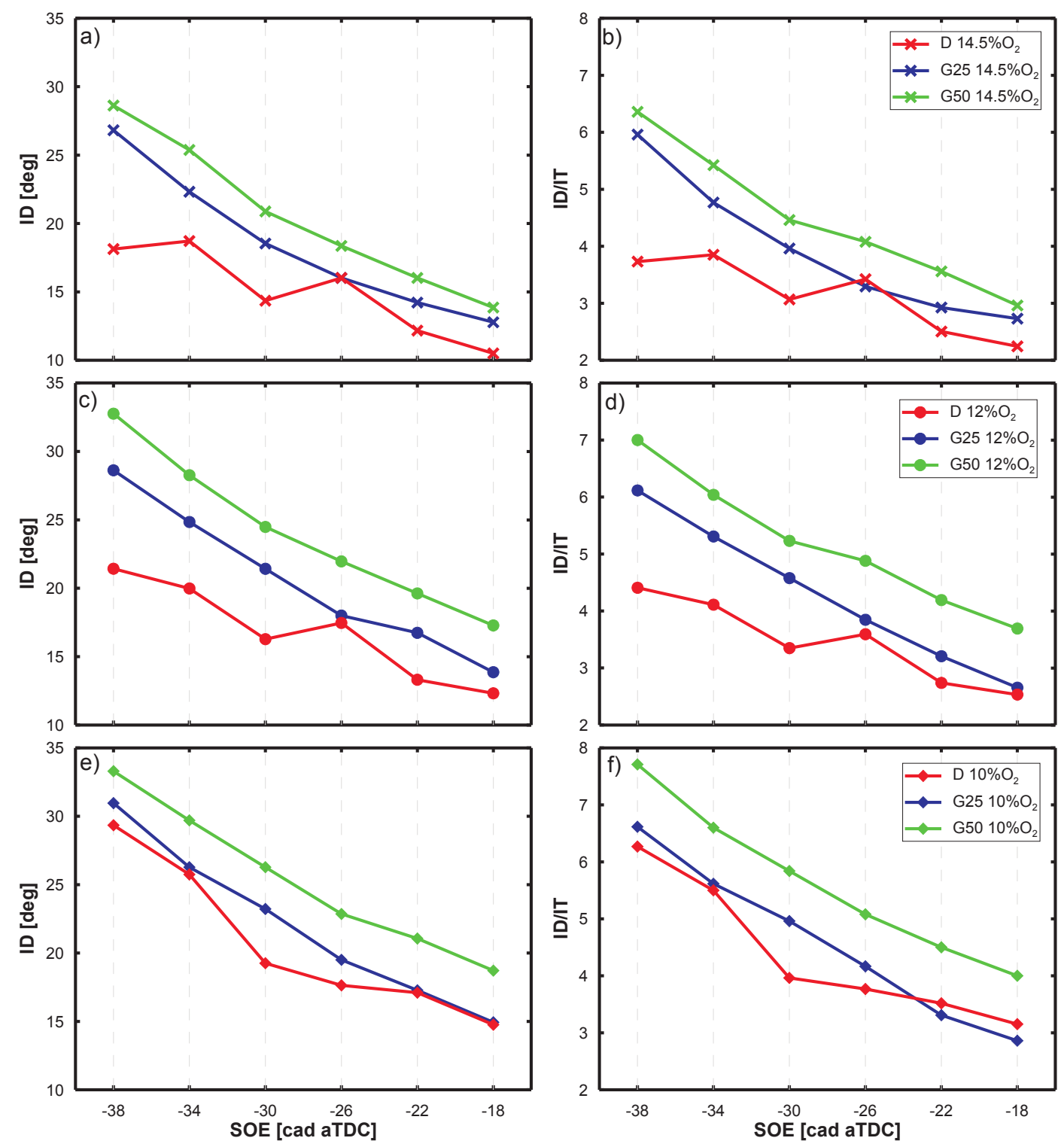

Figure 2: Effect of injection timing, oxygen concentration and fuel on: ID (left column) and ID/IT (right column). 

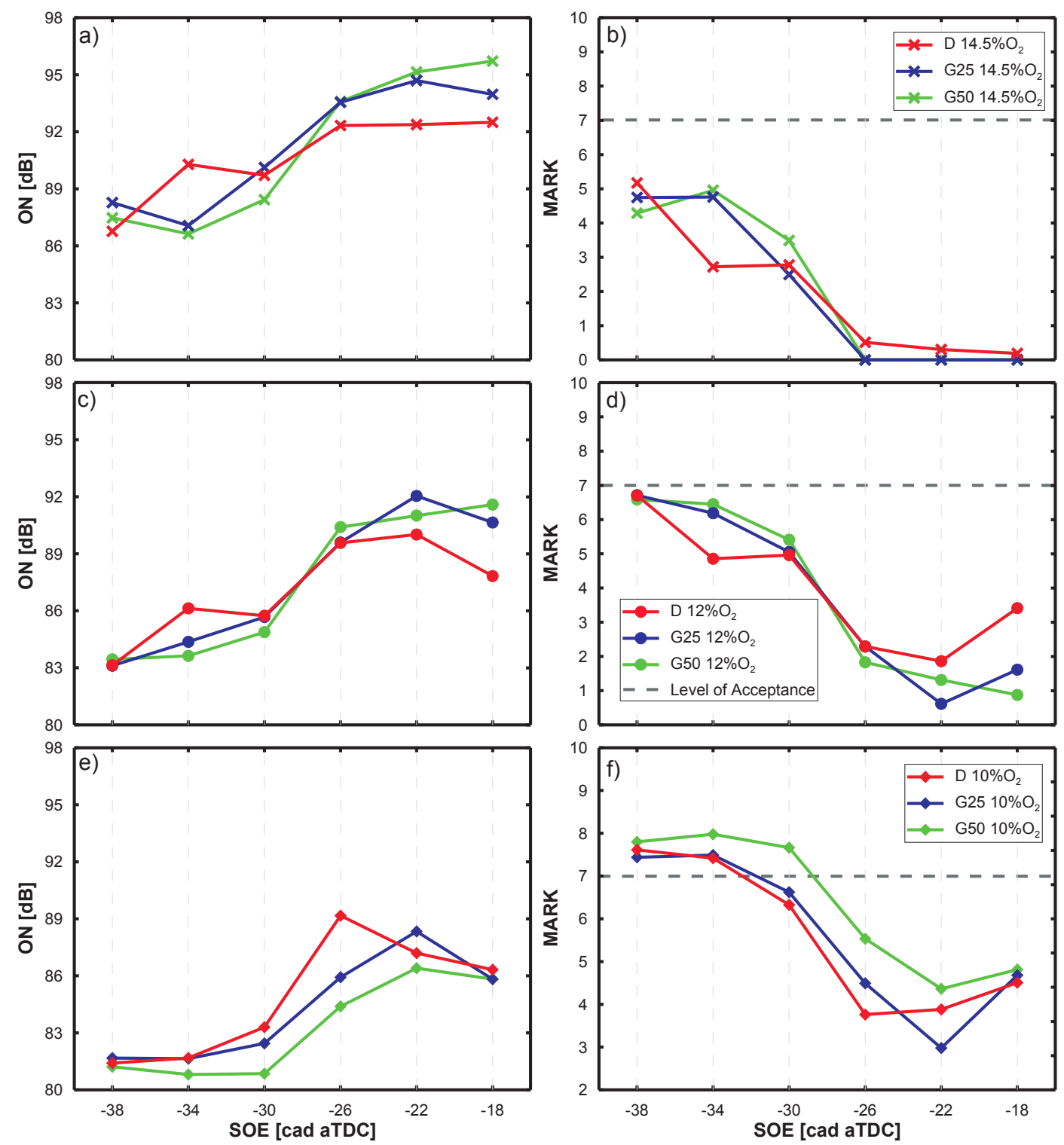

Figure 3: Effect of injection timing, oxygen concentration and fuel on engine noise: ON (left column) and Mark (right column). 

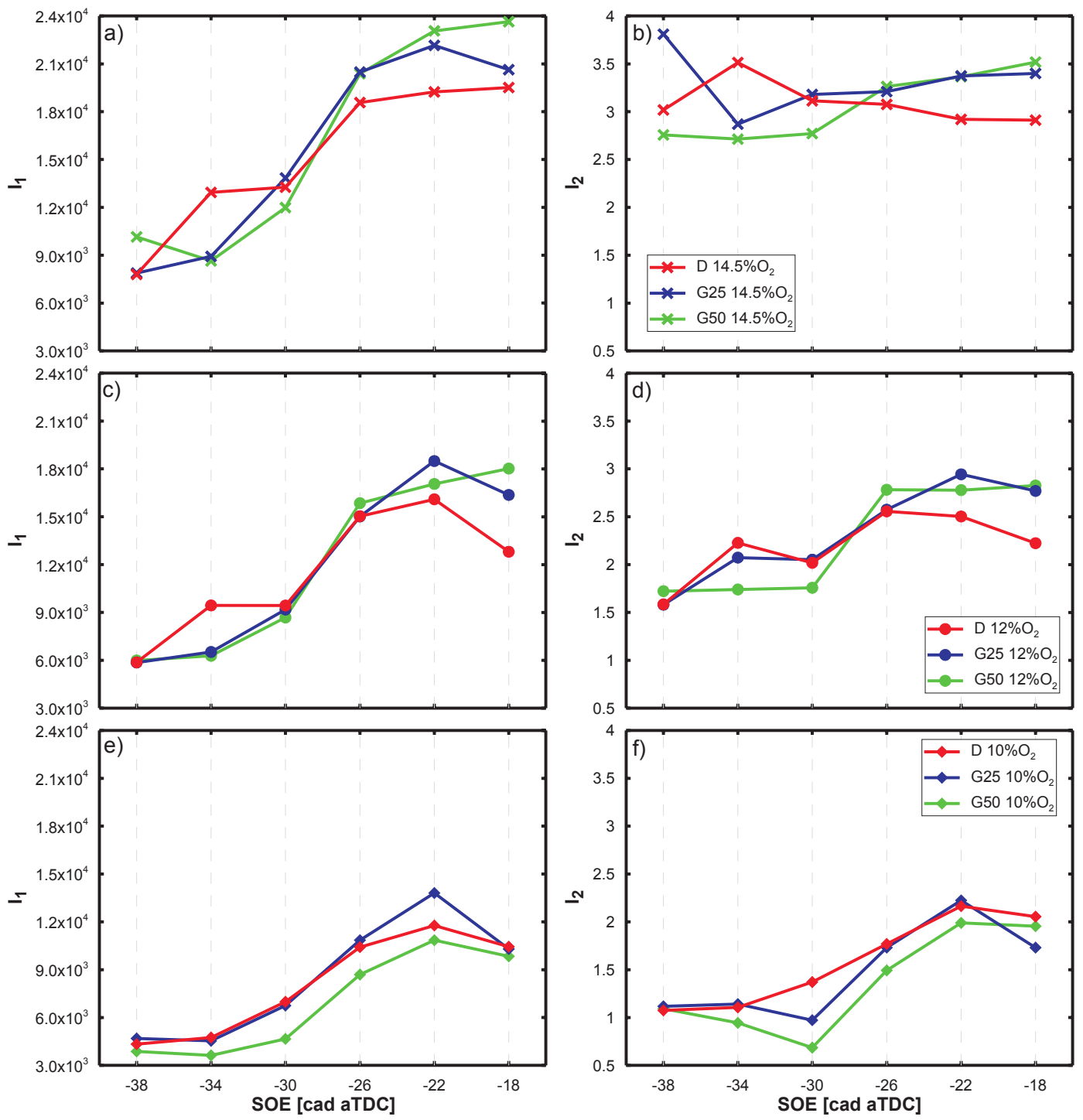

Figure 4: Effect of injection timing, oxygen concentration and fuel on combustion indicators: $I_{1}$ (left column) and $I_{2}$ (right column). 

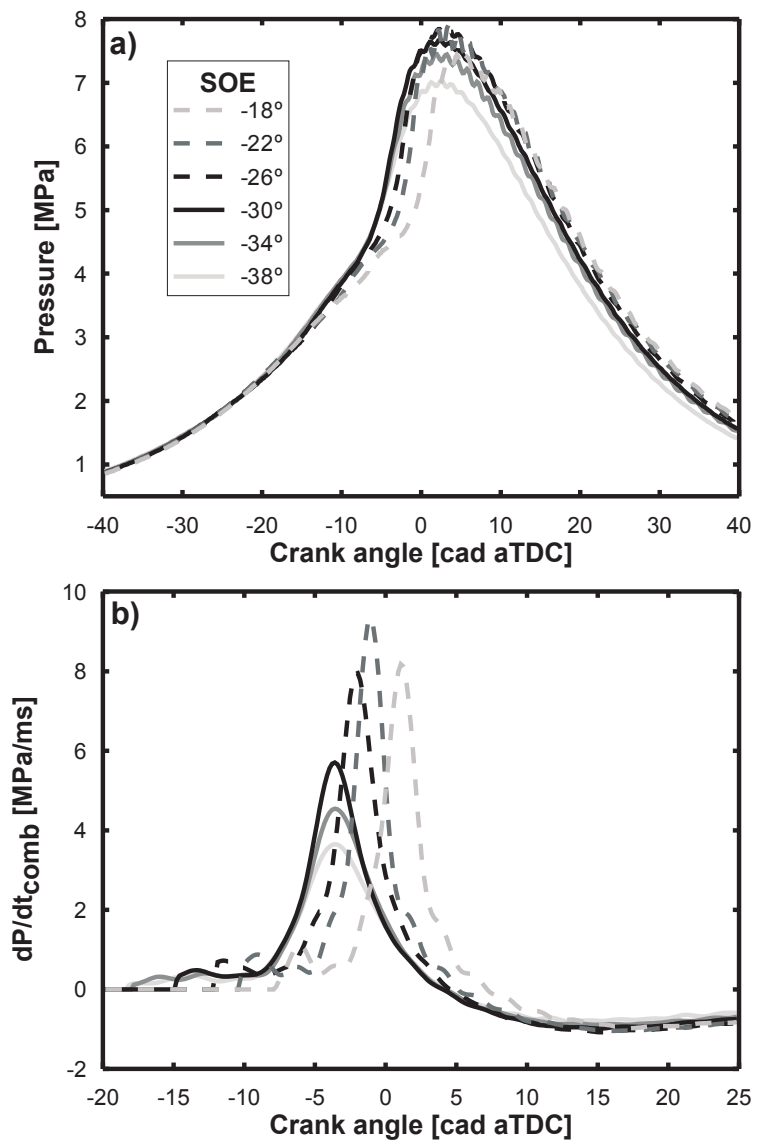

Figure 5: Effect of injection timing on in-cylinder pressure (a) and pressure derivative of the combustion signal (b) for Diesel standard and $\left[\mathrm{O}_{2}\right]_{\mathrm{IN}}$ of $10 \%$. 

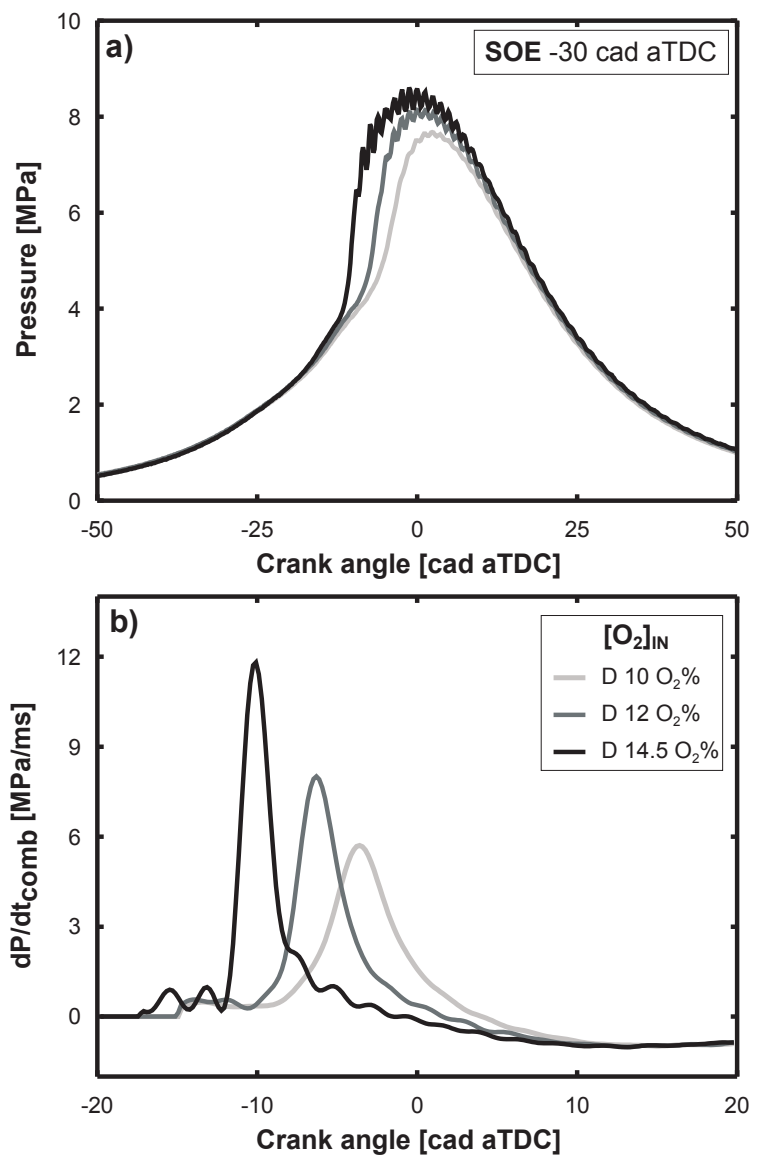

Figure 6: Effect of the $\left[\mathrm{O}_{2}\right]_{\mathrm{IN}}$ on in-cylinder pressure (a) and pressure derivative of the combustion signal (b) for Diesel standard and SOE of -30 cad aTDC. 

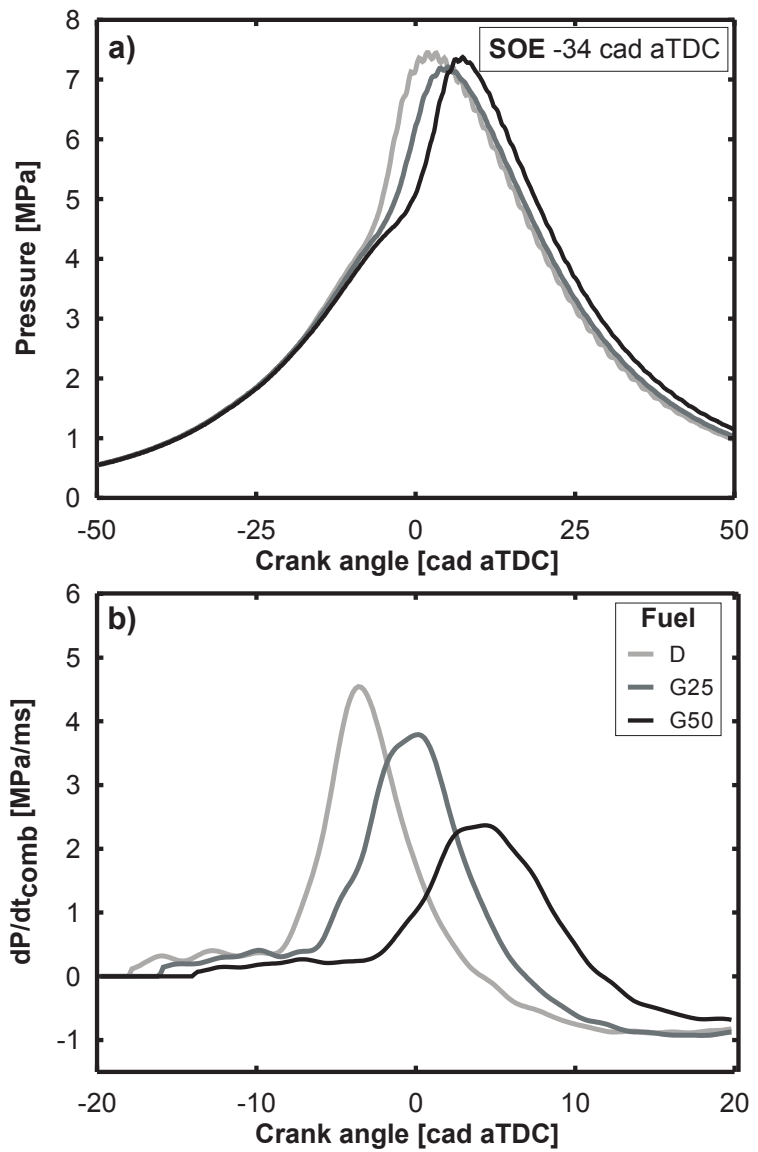

Figure 7: Effect of different fuels on: in-cylinder pressure (a) and pressure derivative of the combustion signal (b) for $\left[\mathrm{O}_{2}\right]_{\mathrm{IN}}$ of $10 \%$ and $\mathrm{SOE}$ of $-34^{\circ} \mathrm{cad}$ aTDC 

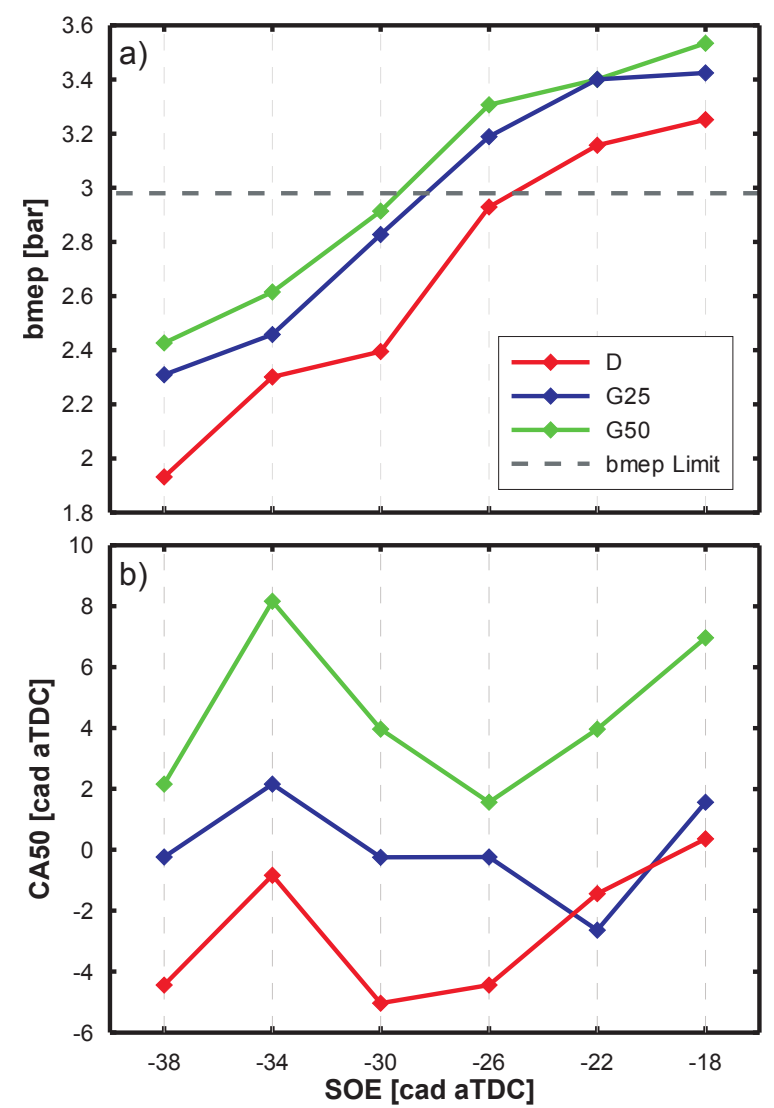

Figure 8: Effect of injection timing and fuel on bmep (a) and CA50 (b) for $\left[\mathrm{O}_{2}\right]_{\mathrm{IN}}$ of $10 \%$. 

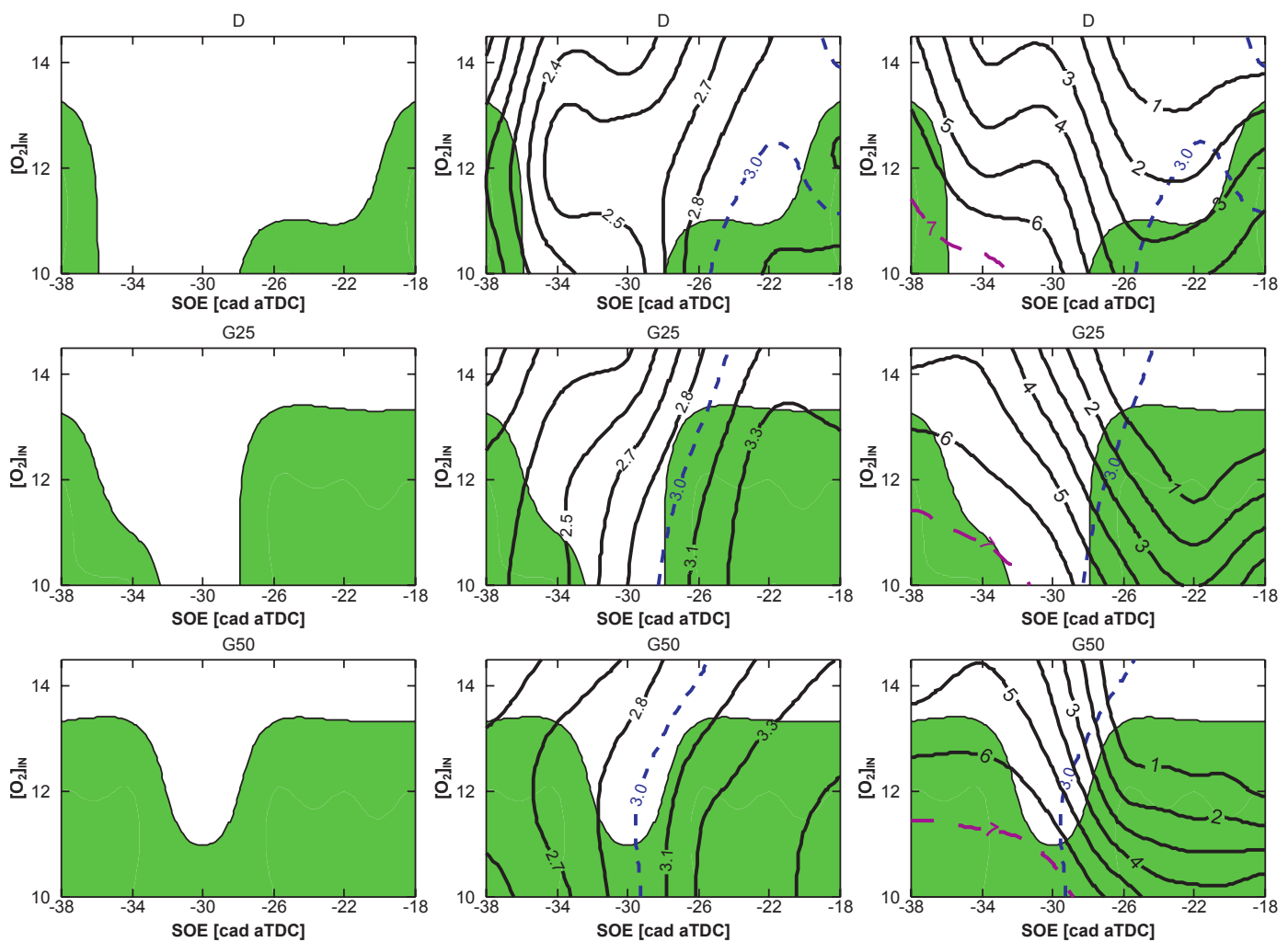

Figure 9: Trade-off maps of pollutant emissions (left column), bmep (center column) and mark (right column) achieved at PCCI combustion with the three types of fuel used: D (top row), G25 (center row) and G50 (bottom row). 